\title{
KOLEKTIVNA SIGURNOST I NJEZINI MEHANIZMI U PAKTU LIGE NARODA
}

Sažetak:

Liga naroda prva je moderna međunarodna organizacija koja je počivala na ideji kolektivne sigurnosti na globalnoj razini. Imajući to u vidu, u radu se nastoji na sustavan način razmotriti kolektivnu sigurnost $i$ njezine mehanizme sadržane $u$ Paktu Lige naroda. U tom cilju, nakon uvodnih razmatranja i kraćeg osvrta na pojmovno određenje, pretpostavke, korijene i kritike kolektivne sigurnosti, u radu se pobliže razmatraju njezini mehanizmi u Paktu Lige naroda kako bi se istražilo, prvo, u kojim su odredbama bili sadržani ti mehanizmi i u čemu su se oni sastojali; drugo, zašto ti mehanizmi nisu uspjeli ostvariti svoju svrhu. Iz tog razloga, zaključci u radu temeljeni su na normativnoj analizi Pakta Lige naroda, ali i na pojedinim primjerima iz povijesti medunarodnih odnosa u tom razdoblju.

Ključne riječi: $\quad$ kolektivna sigurnost, Liga naroda, Pakt Lige naroda

\section{UVODNA RAZMATRANJA}

Nakon što je Pariz u večernjim satima 13. studenoga 2015. po drugi put u samo godinu dana pretrpio teroristički napad, nekoliko dana poslije brojni mediji ${ }^{1}$ prenijeli su vijest da je Francuska od ostalih članica Europske unije službeno zatražila pomoć. Pritom, Francuska, koja je ujedno članica i Ujedinjenih naroda, i Organizacije Sjevernoatlantskog ugovora, i Europske unije, nije se odlučila pozvati na čl. 5. Sjevernoatlantskog ugovora - na koji su se pozvale Sjedinjene Američke Države (dalje: SAD) tražeći pomoć saveznika nakon terorističkog napada 11. rujna 2001. ${ }^{2}$ - nego na tzv. klauzulu o uzajamnoj obrani iz čl. 42. st. 7. Ugovora o Europskoj uniji kojim je propisano da su članici koja je žrtva oružane agresije na svoje državno područje ostale članice Europske unije obvezne pružiti pomoć i potporu svim sredstvima ko-

\footnotetext{
* Gordan Struić, mag. iur., univ. spec. pol., savjetnik u Odboru za Ustav, Poslovnik i politički sustav Hrvatskoga sabora. Hrvatski sabor, Trg sv. Marka 6, 10000 Zagreb, Republika Hrvatska. Adresa e-pošte: gordan.struic@gmail.com. ORCID: http://orcid. org/0000-0001-6528-4436.

$\mathrm{U}$ radu su izneseni osobni stavovi autora.

1 Vidjeti npr. Emmott, R., France makes formal call for EU military help, 2015. URL= http://in.reuters.com/article/france-shootingeu-defence-idINKCNOT60XJ20151117. Pristupljeno 5. ožujka 2017.

2 Vidjeti pobliže: Tabak, I., Kolektivna obrana EU na francuski način, URL= http://obris.org/hrvatska/kolektivna-obrana-eu-nafrancuski-nacin. Pristupljeno 5. ožujka 2017.
} 
jima raspolažu, sukladno čl. 51. Povelje Ujedinjenih naroda. ${ }^{3}$ Time se u središtu europske, ali i svjetske pozornosti našlo pitanje kolektivne sigurnosti.

Spomenuti primjer terorističkog napada na Francusku tek je jedan u nizu onih koji aktualiziraju pitanje razumijevanja sustava kolektivne sigurnosti i ukazuju na važnost učinkovitog funkcioniranja mehanizama ugrađenih u temeljne akte međunarodnih sigurnosnih organizacija. Imajući to u vidu, u radu se nastoji primjenom pravnoga, politološkog i povijesnog pristupa na sustavan način razmotriti kolektivnu sigurnost i njezine mehanizme sadržane u Paktu Lige naroda. U tom cilju, nakon uvodnih razmatranja i kraćeg osvrta na pojmovno određenje, pretpostavke, korijene i kritike kolektivne sigurnosti, u radu se pobliže razmatraju njezini mehanizmi u Paktu Lige naroda kako bi se istražilo, prvo, u kojim su odredbama bili sadržani ti mehanizmi i u čemu su se oni sastojali; drugo, zašto ti mehanizmi nisu uspjeli ostvariti svoju svrhu. Zaključci u radu temeljeni su na normativnoj analizi Pakta Lige naroda, ali i na pojedinim primjerima iz povijesti međunarodnih odnosa u tom razdoblju.

\section{POJMOVNO ODREĐENJE, PRETPOSTAVKE I KRITIKE KOLEKTIVNE SIGURNOSTI}

\subsection{POJMOVNO ODREĐENJE}

Pojam kolektivne sigurnosti prvi put se javlja još 1934., kada ga je u parlamentarnoj debati upotrijebio Churchill, ${ }^{4}$ iako pojedini autori ističu da je dotad već bio u javnoj upotrebi, ${ }^{5}$ a prvi akt neke međunarodne organizacije u kojemu je izrijekom upotrijebljen taj pojam bila je Povelja Organizacije američkih država iz 1948. (poglavlje V. i čl. 44.). ${ }^{6}$

U nastojanju pojmovnog određenja kolektivne sigurnosti Bourne ističe da se ona temelji na načelu da je sigurnost jedne države članice briga svih ostalih država članica i da će se prijetnje sigurnosti susresti s njihovom kolektivnom reakcijom. ${ }^{7}$ Nešto preciznije određenje, koje će poslužiti kao podloga u ovom radu, sadržano je u Pravnom leksikonu prema kojemu kolektivna sigurnost predstavlja "jamstvo zaštite, tj. obrane država” koje su si uzajamno, na temelju međunarodnih ugovora, "obećale pomoć radi obrane svake od njih", a ona se ostvaruje "obvezom tih država da međusobne sporove rješavaju mirnim putem, odnosno da sve priskoče u

3 Povelja Ujedinjenih naroda, Narodne novine, Međunarodni ugovori, broj 15/1993, 7/1994. Prema tom članku ništa u Povelji ne dira u "prirodno pravo individualne ili kolektivne samoobrane u slučaju oružanog napada na nekoga člana Ujedinjenih naroda sve dok Vijeće sigurnosti ne poduzme mjere potrebne za održavanje međunarodnog mira i sigurnosti. Mjere koje članovi poduzmu u vršenju toga prava samoobrane odmah se dojavljuju Vijeću sigurnosti i nipošto ne diraju u ovlasti i dužnosti Vijeća sigurnosti da na temelju ove Povelje djeluje svakog časa na način koji smatra potrebnim za održavanje ili uspostavljanje međunarodnog mira i sigurnosti."

4 McClintock, C., Revolutionary Movements in Latin America: El Salvador's FMLN \& Peru's Shining Path, US Institute of Peace Press, Washington, 1998, str. 333.

5 Sharp, A. Collective Security, URL= www.ieg-ego.eu/sharpa-2013-en. Pristupljeno 5. ožujka 2017.

6 Abass, A., Regional Organisations and the Development of Collective Security: Beyond Chapter VIII of the UN Charter, Hart Publishing, Oxford, Portland, Oregon, 2004, str. 118. Charter of the Organization of American States, URL= http://avalon.law.yale.edu/20thcentury/decad062.asp. Pristupljeno 5. ožujka 2017. 
pomoć onoj od njih čiju je sigurnost ugrozila neka treća država" ${ }^{8} \mathrm{U}$ temelju sustava kolektivne sigurnosti nalazi se primjena načela reciprociteta prema kojemu je svaka država obuhvaćena navedenim sustavom ujedno njime zaštićena i "obvezna zaštititi svaku drugu državu unutar istoga sustava” (Ibid.). Slično tome, Barić u temelju sustava kolektivne sigurnosti ističe važnost suradnje više država utemeljene na prihvatu zajedničkih normi i pravila te usmjerene na očuvanje stabilnosti, uspostavu suradnje i povjerenja među članicama i eventualno zajedničko djelovanje radi sprječavanja agresije, dok je u temelju sustava kolektivne obrane obrambena organizacija koja okuplja države sa zajedničkim pogledom na postojanje specifične prijetnje koja ugrožava vitalne interese svake od njih. ${ }^{9}$

\subsection{PRETPOSTAVKE SUSTAVA KOLEKTIVNE SIGURNOSTI}

Prema Ibleru, sustav kolektivne sigurnosti mora polaziti od pretpostavke da se napadnuta država sama brani od agresora, kao i da sama (može) pruža(ti) agresoru oružani otpor jer bi u protivnom dovela u pitanje političko-pravne temelje vlastite egzistencije. ${ }^{10} \mathrm{Na}$ tom tragu, ističe se važnost triju pretpostavki funkcioniranja kolektivne sigurnosti koje identificira Morgenthau, ali i drugi autori, poput Reutera, Combacaua i Blühdorna. ${ }^{11}$

Prvo, taj sustav u svakom trenutku mora biti sposoban raspolagati nadmoćnim oružanim snagama protiv bilo kojeg agresora ili agresorske koalicije, i to u tolikoj i takvoj mjeri da se agresor neće usuditi dovesti u pitanje pravni poredak, odnosno napasti državu koju bi inače najvjerojatnije napao da tog sustava nema ili da mu ona nije dorasla po svojoj snazi; drugo, države čije su oružane snage u stanju ispuniti prethodnu pretpostavku moraju imati istu predodžbu i zajedničku koncepciju o sigurnosti; treće, prethodno navedene države moraju imati volju i odlučnost sve svoje međusobne političke interese podrediti obrani njihova zajedničkog dobra, pri čemu je obrana tog njihova dobra u interesu svih država u tom sustavu. ${ }^{12}$ Pritom, sve navedene pretpostavke valja kumulativno ostvariti da bi sustav kolektivne sigurnosti mogao učinkovito funkcionirati.

Slično tome, i Vukadinović navodi tri pretpostavke od kojih polazi sustav kolektivne sigurnosti. Prvu od njih predstavlja sila miroljubivih država koja "znatno preteže" nad snagom (potencijalnog) agresora, uz uvjet da svi partneri u sustavu kolektivne sigurnosti prihvate tri načela: ograničenja primjene sile ili eliminiranja korištenja oružane sile, rješavanja sporova mirnim putem i obveznog udruživanja snaga protiv države koja nasilnim sredstvima pokuša narušiti temelje sustava kolektivne sigurnosti. Drugu pretpostavku čini potpuno izjednačavanje nacionalnih interesa država unutar sustava kolektivne sigurnosti, uključujući i potrebu za

8 Pravni leksikon, Leksikografski Zavod Miroslav Krleža, Zagreb, 2007., str. 594. Ibler navodi da kolektivna sigurnost “i po zamisli, i po pozitivnom međunarodnom pravu - određuje da će države unutar dotične organizacije biti zaštićene od agresije, jer će im sve članice organizacije, čitav kolektiv, pružiti zaštitu upotrebom oružanih snaga svih članica", kao i da se u srži ideje kolektivne sigurnosti nalazi formula "svi za jednoga, jedan za sve". Ibler, V., Kolektivna sigurnost i vanjska politika Hrvatske, Politička misao, god. 31, br. 1, 1994., str. 29.-30. Barić, R., Transformacija NATO-a i hrvatska obrambena reforma, Polemos, god. 7, br. 13, 2004., str. 46.

10 Ibler, op. cit. u bilj. 8, str. 31.-32.

11 Ibid.

12 Ibid. 
aktivnim djelovanjem svih država unutar tog sustava protiv agresora, što ujedno zahtijeva i formuliranje obveza organizacijske i pravne naravi. Naposljetku, sustav kolektivne sigurnosti pretpostavlja i postojanje zajedničkog cilja (tj. sigurnost svih država), uz zahtjev za zajedničkom metodom pri zajedničkom i usklađenom djelovanju država u okviru tog sustava. ${ }^{13}$

Wilson ukazuje na to da postoji niz pretpostavki sustava kolektivne sigurnosti koje navode pojedini autori, nastojeći ih općenito svrstati u četiri kategorije. Prvu čine pretpostavke koje zahtijevaju određenu vrstu institucionalnog sustava s pomoću kojeg će sustav kolektivne sigurnosti moći djelovati; drugu čine one koje zahtijevaju univerzalnost, nadmoć i difuziju moći; treću čine one koje se odnose na predanost velikih sila djelovanju sustava kolektivne sigurnosti; četvrtu, koja čini sâmu srž kolektivne sigurnosti, čine pretpostavke koje zahtijevaju da države obuhvaćene tim sustavom prihvate načelo nedjeljivosti mira, ideju da prijetnja sigurnosti jednoj državi predstavlja prijetnju međunarodnoj zajednici kao cjelini. ${ }^{14}$

\subsection{KRITIČKI PRISTUP SUSTAVU KOLEKTIVNE SIGURNOSTI}

Međutim, iako bi za učinkovito funkcioniranje sustava kolektivne sigurnosti valjalo ispuniti sve njegove pretpostavke, prema kritičarima tog sustava iskustva agresije iz vremena Lige naroda (poput Japana na Mandžuriju, Italije na Etiopiju, SSSR-a na Finsku), kao i iskustva iz vremena Ujedinjenih naroda (poput Sjeverne Koreje i Kine na Južnu Koreju, Argentine na Veliku Britaniju, Iraka na Iran i Iraka na Kuvajt), ukazuju na to da ispunjenje tih pretpostavki nije sasvim realno očekivati. ${ }^{15}$ Naime, imperativu sustava kolektivne sigurnosti da obrani status quo suprotstavlja se otvoreno ili prikriveno nastojanje nekih država za njegovim narušavanjem, u čijoj se podlozi nalazi odsutnost međunarodne solidarnosti na koju bi se svaka država mogla osloniti i koja bi interes za očuvanjem mira uzdigla iznad partikularnih interesa pojedinih država. ${ }^{16}$ Zbog toga pluralizam navedenih interesa djeluje paralizirajuće na sustav kolektivne sigurnosti, čineći ga nefunkcionalnim, u čemu kritičari ovog sustava iznalaze potvrdu svoje polazišne tvrdnje da nije sasvim realno očekivati ispunjenje pretpostavki za njegovo učinkovito funkcioniranje, kako to drže Morgenthau i drugi navedeni autori.

Pojašnjavajući kritike sustava kolektivne sigurnosti, Čehulić Vukadinović navodi da - čak i uz stanovitu ravnotežu snaga - različite države obuhvaćene sustavom kolektivne sigurnosti mogu različito percipirati ugroze sigurnosti i stabilnosti, a s obzirom na interne različitosti one imaju različite doprinose ukupnom sustavu, što se posebno ogleda u spremnosti za izdvajanja na planu obrane. ${ }^{17}$ Također, sustav kolektivne sigurnosti zahtijeva uspostavu relativne ravnoteže snaga između država obuhvaćenima tim sustavom jer će, u protivnom, "dominantna sila postati hegemon". ${ }^{18}$ Wilson ističe da postoji cijeli niz kritika sustava kolektivne sigurnosti,

13 Vukadinović, R., Međunarodni politički odnosi, Politička kultura, Zagreb, 2004., str. 159.-161.

Wilson, G., The United Nations and collective security, Routledge, Abingdon, Oxon, 2014., str. 8.-11.

15 Ibler, op. cit. u bilj. 8, str. 32.

16 Ibid., str. 33.

17 Čehulić Vukadinović, L., NATO - od sustava kolektivne sigurnosti do unipolarnog američkog vodstva, Centar za međunarodne studije, Udruga za međunarodne studije, Zagreb, 2003., str. 2. 
no sve one mogu se sažeti u shvaćanju da je kolektivna sigurnost nefunkcionalna upravo stoga što pretpostavke na kojima se ona temelji nije moguće ispuniti, a nastojanja kroz povijest da se kolektivna sigurnost ostvari samo podupiru takvo negativno shvaćanje. ${ }^{19}$

Ipak, unatoč takvim pogledima na djelovanje sustava kolektivne sigurnosti, ne smatraju svi kritičari da taj sustav nikada ne bi mogao funkcionirati ili da je riječ o potpuno promašenoj ideji. ${ }^{20}$ Doima se da takav pristup uvažava činjenicu da neke konfliktne situacije ipak ne prerastaju u rat, iako nije baš posve jasno je li tada riječ isključivo o zasluzi kolektivne sigurnosti ili, pak, o rezultatu (i) nekih drugih čimbenika, poput ravnoteže oružanih snaga. ${ }^{21}$

\section{KORIJENI KOLEKTIVNE SIGURNOSTI}

Korijeni kolektivne sigurnosti sežu u 7. stoljeće pr. n. e., kada je na području današnje Kine 681. godine pr. n. e. osnovan Koncert vladara radi obrane kineskih država od prijetnji koje su im u to vrijeme dolazile od kraljevine Chu. Sustav njihove sigurnosti sastojao se od zajedničkih oružanih snaga te organizacije sastavljenih od vojnih kontingenata država članica radi zaštite njihove teritorijalne cjelovitosti, a među kolektivnim sankcijama - koje su u razdoblju od 681. godine pr. n. e. do 220. godine pr. n. e. (kada je Koncert vladara prestao postojati ujedinjenjem država članica u jedinstvenu kinesku državu) primijenjene samo pet puta - bile su i one koje su uključivale upotrebu sile. ${ }^{22}$ Također, korijeni kolektivne sigurnosti mogu se pronaći i unutar starogrčkih amfiktionija, ${ }^{23}$ saveza čiji su se članovi obvezivali (polagali su zakletvu) da neće uništiti niti jednog člana tog saveza, odnosno da će se osvetiti bilo kojemu članu saveza koji je prekršio tu zakletvu. ${ }^{24}$ Još jasnije obrise kolektivne sigurnosti valjalo bi prepoznati u sustavu formiranom 1000. godine, Koncilom u Poitiersu koji je obvezivao sve države članice da pomognu napadnutoj državi radi odbijanja agresije i “osvete pravde”, a nakon što je učvršćen Verdunskim koncilom 1016. i znatnije centraliziran Koncilom u Bourgesu 1038. formiranjem oblika zajedničkih oružanih snaga država članica, taj sustav potvrđen je i u aktima koncila u Clermontu, Reimsu te Trećeg lateranskog koncila $1179 .{ }^{25}$ Usto, vrijedi istaknuti i sporazum Engleske i Francuske iz 1655., kao primjer prvoga međunarodnog sporazuma koji je predviđao mjere ekonomske naravi kao sredstva kolektivne sigurnosti, među kojima je bila i zabrana trgovine, a nakon njega slijedili su i drugi slični sporazumi: Engleske i Švedske iz 1661., Nizozemske i Alžira iz 1662. te Nizozemske i Švedske iz $1667 .^{26}$

\footnotetext{
19 Wilson, op. cit. u bilj. 14, str. 14.

$20 \quad$ Ibler, op. cit. u bilj. 8, str. 33.

21 Isti autor smatra da bi razloge jer, unatoč suprotstavljenim blokovima u hladnoratovskom razdoblju, nije došlo do velikoga svjetskog rata valjalo tražiti u ravnoteži oružanih snaga, tj. njihova atomskog oružja (ibid., str. 34.).

22 Lapaš, D., Pravo međunarodnih organizacija, Narodne novine, Zagreb, 2008., str. 18.

23 Riječ je o savezima starogrčkih gradova-država kao svojevrsnim pretečama "suvremenih (ponajprije obrambenih) međunarodnih organizacija”. Lapaš, D., Međunarodna organizacija kao stranka međunarodnog spora, Zbornik Pravnog fakulteta u Zagrebu, god. 62, br. 1-2, 2012., str. 712.

24 Tsagourias, N.; White, N. D., Collective Security: Theory, Law and Practice, Cambridge University Press, Cambridge, 2013 , str. 4.

25 Lapaš, op. cit. u bilj. 22, str. 20.

26 Abass, op. cit. u bilj. 6, str. 115 .
} 
Nadalje, načela kolektivne sigurnosti sadržavao je i Vestfalski sporazum ${ }^{27}$ iz 1648., koji je u čl. CXXIV. predviđao da su u slučaju nemogućnosti strana u sporu da u roku od tri godine na miran način riješe svoj spor sve ostale potpisnice tog sporazuma obvezne pridružiti i pomoći potpisnici u odbijanju napada na nju, a slične odredbe vidljive su i u Chaumontskom sporazu$\mathrm{mu}^{28}$ iz 1814. koji je u čl. VI. predviđao suglasnost sporazumnih strana da u slučaju prijetnje napadom na koju od njih od strane Francuske poduzmu svoje najviše napore kako bi je u tome spriječile svojim prijateljskim posredovanjem, dok je u čl. VII. bilo predviđeno da će, u slučaju neučinkovitosti tih napora, svaka od njih odmah pomoći napadnutoj strani sa 60.000 ljudi. Međutim, u međunarodnoj praksi ta načela nisu bila poštovana, nego je međunarodni poredak bio temeljen na načelu ravnoteže snaga, sve do 20. stoljeća. ${ }^{29}$ To potvrđuje Sveta alijansa, svojevrsna oligarhija najmoćnijih europskih država čiji su se vladari (ruski car Aleksandar I., austrijski car Franjo I. i pruski kralj Fridrik Vilim III.) obvezali prema čl. 1. sporazuma iz 1815. da "u svim prilikama i na svim mjestima pruže jedan drugome pomoć i podršku", ${ }^{30}$ ali su se vojne intervencije država članica u pravilu provodile tek da bi se zaštitilo političko uređenje od revolucija, poput intervencije Francuske u Španjolskoj 1823. uz pristanak Austrije, Prusije i Rusije ili intervencije Engleske u Portugalu 1826. ${ }^{31}$ Budući da je o vojnim intervencijama, ali i drugim važnim (međunarodnim) problemima bilo potrebno donijeti zajedničku odluku na konferencijama, Sveta alijansa smatra se prethodnicom Lige naroda i Ujedinjenih naroda. ${ }^{32}$

\section{KOLEKTIVNA SIGURNOST PREMA PAKTU LIGE NARODA}

\subsection{OSNIVANJE LIGE NARODA}

Prvi koraci u procesu formiranja Lige naroda, prve moderne međunarodne organizacije koja je počivala na ideji kolektivne sigurnosti na globalnoj razini, učinjeni su tijekom Prvoga svjetskog rata, u nastojanju da se pripreme temelji za postizanje trajnog mira. Uz izjave niza državnika, od kojih su najvećeg odjeka imale one predsjednika SAD-a Wilsona o osnivanju zajednice naroda (npr. u govoru od 27. svibnja 1916. ${ }^{33}$ ), prijedloga različitih skupina, od kojih

27 Treaty of Westphalia, URL= http://avalon.law.yale.edu/17th_century/westphal.asp. Pristupljeno 5. ožujka 2017.

28 British and Foreign State Papers 1812-1814, Vol. I, Part. I., James Ridgway and Sons, London, 1841, str. 125.-129.

29 Ejdus, F., Međunarodna bezbednost: teorije, sektori i nivoi, Službeni glasnik, Beograd, 2012., str. 28.

30 Pariški sporazum o Svetoj alijansi iz 1815., vidi: Osmańczyk, E. J.; Mango, A., Encyclopedia of the United Nations and International Agreements: G to M, Routledge, New York, 2003, str. 910.-911.

31 Lapaš, op. cit. u bilj. 22, str. 21. Isti autor navodi i slično djelovanje Koncerta europskih velevlasti koji je formiran po raspadu Svete alijanse.

Ginneken, A. H. M. Van, Historical Dictionary of the League of Nations, Scarecrow Press, Lanham, Toronto, Oxford, 2006, str. 1.

Vidjeti: Woodrow Wilson, Address delivered at the First Annual Assemblage of the League to Enforce Peace: "American Principles", URL= http://www.presidency.ucsb.edu/ws/?pid=65391. Pristupljeno 5. ožujka 2017. Wilson je 8. siječnja 1918. u svom obraćanju Kongresu izložio 14 točaka koje su činile ciljeve SAD-a u Prvom svjetskom ratu, a posljednja, XIV. točka pozivala je na stvaranje "opće udruge nacija" (vidjeti pobliže: President Woodrow Wilson's Fourteen Points, URL= http://avalon.law.yale.edu/20th-century/ wilson14.asp. Pristupljeno 5. ožujka 2017.). Međutim, samo tri dana prije, 5. siječnja 1918. već je britanski predsjednik vlade Lloyd George govorom na konferenciji sindikata među osnovnim uvjetima za pravedan i trajan mir spomenuo upravo taj da se osnuje "Internacionalna organizacija koja će omogućiti smanjenje naoružanja, a time i opasnosti od izbijanja novih ratova" (Kardum, L. Suton stare Europe: europska diplomacija i Prvi svjetski rat, Golden marketing - Tehnička knjiga, Zagreb, 2009., str. 240.-245.). Usto, zamisao o Ligi naroda nije potekla od Wilsona, nego od lorda Phillimorea, međunarodnog pravnika koji 
se isticala Liga za provedbu mira ${ }^{34}$ utemeljena u SAD-u 1915., svoj doprinos na tom planu davale su i vlade pojedinih zaraćenih i neutralnih država. Potkraj Prvoga svjetskoga rata, uz 40 različitih privatnih nacrta o budućoj mirovnoj organizaciji, spominje se jedanaest takvih službenih nacrta, i to: sedam savezničkih, tri neutralna i jedan njemački nacrt. ${ }^{35}$ Jedan od najvažnijih takvih nacrta bio je formuliran od strane odbora koji je imenovala britanska vlada od stručnjaka iz redova povjesničara, diplomata i pravnika pod predsjedanjem lorda Phillimorea koji je predvidio cijeli mehanizam sa sankcijama (detaljnije je razrađen u čl. 12. Pakta), a taj nacrt predsjednik Wilson uputio je 1918. svom bliskom suradniku, pukovniku Houseu koji je u nacrt ugradio sredstva mirnog rješavanja sporova, dok je sankcije ograničio na one ekonomske naravi. ${ }^{36}$ Wilson je smatrao da nova međunarodna organizacija treba imati vijeće za rješavanje sporova pa tek "ako vijeće ne uspije riješiti spor, državu koja prekrši pravila treba staviti izvan zakona (...)", ističući i da "stari sustav ovlasti i ravnoteže moći prečesto je zatajivao". ${ }^{37}$ Stoga, nastojalo se formirati takvu organizaciju koja će ukloniti sustav ravnoteže snaga i, općenito, mogućnost nastanka nekih budućih ratova na svjetskoj razini putem obveze provođenja dugotrajnih postupaka rješavanja sporova za članicu koja je htjela zaratiti protiv druge članice, odnosno kroz primjenu ekonomskih (i eventualno vojnih) sankcija od strane svih drugih članica Lige naroda u slučaju da bilo koja od njih prekrši obveze iz Pakta Lige naroda i krene u rat; pritom je dugotrajna procedura zamišljena kao ključno sredstvo koje će omogućiti da "mirotvoran pritisak svjetskoga javnog mnijenja (...) stiša strasti i (...) onemogući sukob.”38

Konačni nacrt Pakta Lige naroda izložen je na plenarnoj sjednici mirovne konferencije u Parizu 28. travnja 1919., kada je jednoglasno prihvaćen, no kao službeni datum formiranja Lige naroda uzima se tek 10. siječnja 1920., kada je stupio na snagu Versailleski mirovni sporazum ${ }^{39}$ čiji je Pakt Lige naroda sastavni dio. Unatoč ključnoj ulozi predsjednika Wilsona u promicanju ideje o Ligi naroda i kolektivnoj sigurnosti na globalnoj razini, SAD nikada nije pristupio Ligi naroda, što se pripisuje tome da su protivnici članstva na čelu sa senatorom Lodgeom vezali takve rezerve uz ugovor o pristupanju da je dosezanje potrebne dvotrećinske većine de facto postalo nemoguće, ${ }^{40}$ a takvog izolacionizma SAD nije se odrekao do "posljednjih dana svjetskog mira". ${ }^{41}$

je predsjedao povjerenstvom ministarstva vanjskih poslova čije je izvješće skovalo prijedlog 20. ožujka 1918. i lorda Cecila, torijevskog zastupnika u britanskom parlamentu koji je bio i državni podtajnik za vanjske poslove (Johnson, P., Moderna vremena: povijest svijeta od 1920-ih do 2000, Golden marketing - Tehnička knjiga, Zagreb, 2007., str. 38.), dok je tvorac sâmog naziva "Liga naroda" bio Dickinson koji je utemeljio Uniju Lige naroda (ibid., str. 177.).

Za usporedni prikaz predloženog i usvojenog teksta Pakta Lige naroda vidi: Gerrity, F. X. (ur.), Taft Papers on the League of Nations, Vol. 7, The Collected Works of William Howard Taft, Ohio University Press, Athens, 2003., str. 8.-35.

Andrassy, J., Liga naroda: njezino ustrojstvo i djelovanje, Izdanje Pramatice Nakl. K. D: Petar Kvaternik i drugovi, Zagreb, 1931., str. 9 .

Ibid., str. 10.

MacMillan, M., Mirotvorci: šest mjeseci koji su promijenili svijet, Naklada Ljevak, Zagreb, 2008., str. 41.

Degan, V.-Đ., Odgovornost za zločin agresije u svim njegovim aspektima, Rad Hrvatske akademije znanosti i umjetnosti, Razred za društvene znanosti, br. 510=48, 2011., str. 238.

Treaty of Versailles, URL= http://loc.gov/law/help/us-treaties/bevans/m-ust000002-0043.pdf. Pristupljeno 5. ožujka 2017.

Bennett, A. L.; Oliver, J. K., Međunarodne organizacije, Politička kultura, Zagreb, 2004., str. 36.

Lovrenčić, R., Nemirni mir: svijet 1918.-1939., Mala zvona, Zagreb, 2011., str. 67. 


\subsection{KOLEKTIVNA SIGURNOST PREMA PAKTU LIGE NARODA}

Pakt Lige naroda ${ }^{42}$ činio je ustav te organizacije koji je bio sadržan u mirovnim sporazumima (kao njihov prvi dio) između savezničkih i udruženih vlasti i Njemačke, odnosno Austrije, Bugarske i Mađarske no postojao je i izvan njih i neovisno od njih. ${ }^{43} \mathrm{U}$ smislu kolektivne sigurnosti valjalo bi najprije izdvojiti čl. 10. Pakta Lige naroda kojim je bila predviđena obveza članica Lige naroda da poštuju i održavaju protiv svakoga vanjskog napada teritorijalni integritet i političku neovisnost svake njezine članice, (dakle, status quo) s time da se u slučaju napada, prijetnje ili opasnosti od takvog napada vijeće Lige naroda brine o sredstvima kojima se osigurava izvršenje te obveze. ${ }^{44}$ S obzirom na takvu stipulaciju čl. 10., vidljivo je da su izvan njezina domašaja ostali mogući oblici napada iznutra, poput ustanaka. Riječ je, inače, o odredbi koju je Wilson smatrao jednim od temeljnih načela uređenja svijeta no upravo ta odredba imala je najveći utjecaj na neprihvaćanje Pakta od strane SAD-a. ${ }^{45}$ Ista odredba bila je na meti kritika i kanadskih državnika koji su smatrali da bi zbog primjene čl. 10. Kanada morala vojno intervenirati i u dalekim područjima pa su zahtijevali ukidanje te odredbe; ipak, nakon niza rasprava odredba čl. 10. je zadržana, ali je njezin domašaj oslabljen time što bi u slučaju napada iz čl. 10. najprije vijeće moralo utvrditi činjenicu da je doista došlo do napada i zatim predložiti (preporučiti) članicama koje bi se mjere, s obzirom na konkretne okolnosti, trebale poduzeti, a svaka članica imala je pravo procijeniti u kojem bi se opsegu te mjere izvršile. ${ }^{46} \mathrm{Na}$ tu odredbu čl. 10. nadovezivao se čl. 11. st. 1 . o preventivnom djelovanju, kojim je bilo propisano da je svaki rat ili prijetnja ratom od interesa za čitavu Ligu naroda i da ona mora poduzeti prikladne mjere za očuvanje mira među narodima. U takvom slučaju, glavni tajnik bez odgađanja sazvao bi vijeće po zahtjevu bilo koje članice. Primjer takve primjene čl. 11. bio je u pograničnom sukobu Grčke i Bugarske 1925., kada je Liga naroda najprije od njih zatražila da obustave neprijateljstva, zatim ih je opomenula na obveze iz Pakta Lige naroda, a potom kolektivno posredovala između njih kako bi pristale da se provede istraga i uredi sporno pitanje. ${ }^{47}$

Pakt Lige naroda sadržavao je razrađen sustav prevencije oružanih sukoba. Naime, u čl. 12. st. 1. bila je propisana obveza članica da svaki spor najprije pokušaju riješiti mirnim putem, a izbor sredstva bio je prepušten njihovoj volji: mogle su birati između arbitražnog, odnosno sudskog postupka i ispitivanja od strane vijeća Lige naroda, uz obvezu da ne pribjegnu ratu prije proteka roka od tri mjeseca od arbitražne, odnosno sudske odluke ili izvješća vijeća. Navedenu odluku bilo je potrebno donijeti u primjerenom roku, a izvješće vijeća u roku od šest mjeseci od dana podnošenja spora (čl. 12. st. 2.). Ako je izvješće vijeća bilo jednoglasno prihvaćeno, članice su se obvezale da neće pribjeći ratu protiv članice koja se držala preporuka izvješća (čl. 15. st. 6.) no ako izvješće nije bilo jednoglasno prihvaćeno, članice su imale pravo postupati kako god su držale potrebnim za "očuvanje prava i pravednosti" (čl. 15. st. 7.), čime je bila ostavljena otvorenom i mogućnost rata. Daljnja razrada tog sustava prevencije bila je uređena u čl. 13.-15.

The Covenant of the League of Nations, URL= http://avalon.law.yale.edu/20th-century/leagcov.asp. Pristupljeno 5. ožujka 2017.

Andrassy, op. cit. u bilj. 35, str. 15.

Paktom Lige naroda bila su predviđena tri glavna tijela Lige naroda: Skupština (koju su činili predstavnici članica), vijeće (koje su činili predstavnici određenih država koje su u njemu bile stalno predstavljene, dok je druge birala skupština na određeno vrijeme) i tajništvo (koje su činili glavni tajnik, tajnici i potrebno pomoćno osoblje).

Andrassy, op. cit. u bilj. 35, str. 155.-156.

Ibid., str. 157.

Ibid., str. 171. 
Iz toga slijedi da je Pakt Lige naroda primarno bio usmjeren na prevenciju oružanih sukoba, no u slučaju povrede prethodno spomenutih obveza bili su stvoreni preduvjeti za primjenu čl. 16. kojim su bile propisane sankcije. U čl. 16. st. 1. tako je bilo propisano da će se - ako bi bilo koja članica stupila u rat protivno obvezama iz čl. 12., 13. i 15. - smatrati, ipso facto, da je stupila u rat protiv svih ostalih članica, a one su je odmah bile obvezne podvrgnuti prekidu svih trgovinskih, financijskih ili osobnih odnosa između njihovih državljana i državljana članice koja je povrijedila te odredbe, kao i obustavi svih financijskih, trgovinskih ili osobnih odnosa između njihovih državljana i državljana članice koja je prekršila odredbe Pakta Lige naroda, i to neovisno o tome jesu li te države članice Lige naroda. Nadalje, na temelju čl. 16. st. 2. vijeće Lige naroda moralo je preporučiti vladama članica kojim učinkovitim vojnim, pomorskim ili zračnim snagama svaka od njih doprinosi oružanim snagama u cilju zaštite zajedničkih obveza. U primjeni ekonomskih i financijskih mjera koje je na temelju čl. 16. st. 1. trebalo poduzeti članice su prema čl. 16. st. 3. bile obvezne jedna drugoj pružati uzajamnu pomoć da bi se na najmanju mjeru sveli gubici i nezgode, kao i da odole svakoj mjeri od strane države koja je prekršila odredbe Pakta Lige naroda. S obzirom na tu odredbu o uzajamnoj pomoći, 1930. sklopljen je Ugovor o financijskoj pomoći ${ }^{48}$ kojim je vijeće Lige naroda moglo članici koja je napadnuta ili joj je napad prijetio, i to tek ako se mir nikako drukčije nije mogao održati ili uspostaviti, odobriti financijsku pomoć sukladno čl. 7. st. 1. tog Ugovora u formi zajma s maksimalnim iznosom do 100 milijuna zlatnih franaka. ${ }^{49}$

Naposljetku, u čl. 16. st. 3. Pakta Lige naroda bilo je određeno i da su članice bile obvezne olakšati prolaz kroz svoj teritorij snagama svake članice Lige naroda koja je sudjelovala u zajedničkoj akciji, a u čl. 16. st. 4. da svaka članica koja se ogriješila o neke obveze iz Pakta Lige naroda može (drugim riječima, ne mora) biti isključena iz članstva Lige naroda, s time da je do njezina isključenja dolazilo glasovanjem ostalih članica koje su bile zastupane u vijeću Lige naroda.

\subsection{KOMPLEMENTARNI SIGURNOSNI MEHANIZMI}

S obzirom na to da navedene odredbe nisu isključivale mogućnost rata, vrijedi spomenuti zanimljiv dodatni sigurnosni mehanizam koji je bio sadržan u čl. 21. Naime, njime je bilo određeno da odredbe Pakta Lige naroda neće utjecati na valjanost međunarodnih obveza, poput sporazuma o arbitraži i regionalnih sporazuma, kao što je Monroeva doktrina, ${ }^{50}$ kojima se osigurava očuvanje mira. U tom svjetlu omogućena je primjena komplementarnih sigurnosnih mehanizama, primjerice, u okviru Sporazuma o uzajamnom jamstvu između Njemačke, Belgije, Francuske, Velike Britanije i Italije ${ }^{51}$ iz 1925., kojim je u čl. 1. bilo propisano da ugovorne strane zajednički i

48 Convention on financial assistance, URL= http://digital.library.northwestern.edu/league/le000037.pdf. Pristupljeno 5. ožujka 2017.

49 Andrassy, op. cit. u bilj. 35, str. 173.

50 Monroeova doktrina je naziv za dva temeljna načela vanjske politike SAD-a što ih je u svojoj poruci Kongresu 2. prosinca 1823. formulirao tadašnji predsjednik SAD-a James Monroe, prema kojima "SAD neće trpjeti punu slobodu djelovanja neameričkih država na američkom kontinentu, a same sebi nameću isto ograničenje slobode u svojoj politici na evropskom kontinentu”. Ibler, V., Rječnik međunarodnog javnog prava, Informator, Zagreb, 1987., str. 177.

51 Treaty of Mutual Guarantee between Germany, Belgium, France, Great Britain and Italy; October 16, 1925 (The Locarno Pact), URL= http://avalon.law.yale.edu/20th-century/locarno-001.asp. Pristupljeno 5. ožujka 2017. 
pojedinačno jamče da će održati teritorijalni status quo koji proizlazi iz granica između Njemačke i Belgije i između Njemačke i Francuske te nepovredivost tih granica određenih Versailleskim mirovnim sporazumom iz 1919. Tim sporazumom Njemačka i Belgija te Njemačka i Francuska uzajamno su se obvezale u čl. 2. da se neće međusobno napadati, izvršiti invaziju ili posegnuti za ratom, osim radi ostvarenja prava na legitimnu obranu, tj. otpora protiv kršenja obveza sadržanih u čl. 1. tog sporazuma ili očite povrede odredbi čl. 42. i 43. Versailleskoga mirovnog sporazuma, ako takva povreda predstavlja nepotaknuti čin agresije ili kada je nužno neposredno djelovanje oružanih snaga u demilitariziranim zonama; radi djelovanja sukladno čl. 16. Pakta Lige naroda; i radi djelovanja koje je rezultat odluke skupštine ili vijeća Lige naroda ili postupanja u skladu s čl. 15. st. 7. Pakta Lige naroda, ali pod uvjetom da je ono usmjereno protiv države koja je prva izvršila napad. Cilj tog sporazuma jasno je bio iskazan u čl. 7. kojim je explicite bilo određeno da je osmišljen kako bi se osiguralo očuvanje mira, da je usklađen s Paktom Lige naroda i da se ne smije interpretirati kao ograničavanje obveze Lige naroda da poduzima bilo koje djelovanje koje se može smatrati mudrim i učinkovitim u osiguranju mira u svijetu.

Budući da Pakt Lige naroda nije u cijelosti zabranjivao rat, 27. kolovoza 1928. potpisan je Ugovor o odricanju od rata (kao instrumenta nacionalne politike), poznatiji kao Briand-Kelloggov pakt ${ }^{52}$ kojim je u čl. 1. određeno da visoke ugovorne stranke svečano objavljuju u ime svojih naroda da osuđuju pribjegavanje ratu radi rješavanja međunarodnih sporova, kao i da ga se odriču kao instrumenta nacionalne politike u svojim uzajamnim odnosima, a u čl. 2. da se slažu da će sve svoje sporove i sukobe bilo koje naravi ili njihova porijekla, koji među njima mogu nastati, rješavati samo mirnim putem. Međutim, Briand-Kelloggov pakt dopuštao je rat koji je vođen u samoobrani, kao i rat u provedbi međunarodnih obveza koje proizlaze iz Pakta Lige naroda te protiv država koje su se ogriješile o njegove odredbe, a kao nedostatak njegova sigurnosnog mehanizma uglavnom se uzima to što nije sadržavao odgovarajući sustav rješavanja sporova i ostalih mjera za prevenciju konflikta, baš kao ni organizaciju kolektivnih sankcija protiv onih država koje su prekršile njegove odredbe. ${ }^{53}$ Usto, valjalo bi imati u vidu i da je Briand-Kelloggov pakt djelovao isključivo među državama koje su ga potpisale, iz čega slijedi da upotreba oružane sile u svim drugim slučajevima nije bila zabranjena, a takvo stanje potrajalo je sve do donošenja Povelje Ujedinjenih naroda, kada je ta zabrana postala apsolutna.

\subsection{PRIMJENA ODREDBI U PRAKSI}

Iako je Pakt Lige naroda sadržavao razrađen sustav prevencije oružanih sukoba, odredbe tog sustava nisu ih u cijelosti eliminirale. Primjerice, s obzirom na stipulaciju čl. 10., vidljivo je da su izvan njezina domašaja ostali mogući oblici napada internog karaktera, poput ustanaka, dok se iz čl. 12. st. 1. nameće zaključak da je obveza članica (da mirnim putem riješe spor i ne pribjegnu ratu prije nego što protekne rok od tri mjeseca od arbitražne, odnosno sudske odluke ili izvješća vijeća) prestajala po proteku tog roka od tri mjeseca, čineći rat i dalje dijelom međunarod-

52 Briand-Kellogg Pact, URL= http://avalon.law.yale.edu/20th-century/kbpact.asp. Pristupljeno 5. ožujka 2017. Republika Hrvatska stranka je tog Ugovora od 8. listopada 1991. Vidi: Odluka o objavljivanju mnogostranih međunarodnih ugovora kojih je Republika Hrvatska stranka na temelju notifikacije o sukcesiji, Narodne novine, Međunarodni ugovori, br. 3/1995. 
nopravnih odnosa. ${ }^{54}$ Jednako tako, do rata je posve legitimno moglo doći i, primjerice, onda kada izvješće nije bilo jednoglasno prihvaćeno na temelju čl. 15. st. 6. ili onda kada izvješće nije bilo doneseno u propisanom roku od šest mjeseci na temelju čl. 12. st. 2., iz čega slijedi da su ratovi bili dopušteni u svim onim slučajevima kada su države poštovale postupovne odredbe i rokove koje je predviđao Pakt Lige naroda. Iako je čl. 16. činio važnu odredbu sa stajališta kolektivne sigurnosti, budući da su njime bile propisane sankcije, vijeće Lige naroda moglo je tek preporučiti vladama članica kojim (i kolikim) snagama svaka od njih doprinosi oružanim snagama na temelju čl. 16. st. 2., što je uvelike oslabilo sigurnosni potencijal tog mehanizma u cilju zaštite zajedničkih obveza. Usto, čak i kada se pojedina članica ogriješila o određene obveze iz Pakta Lige naroda, čl. 16. st. 4. otvarao joj je mogućnost da ipak ne bude isključena iz članstva Lige naroda.

Imajući u vidu navedene nedostatke, valjalo bi promotriti kako su se obveze iz Pakta Lige naroda i sankcije iz čl. 16. ostvarivale u praksi. Kao primjer uspješnog djelovanja Lige naroda može se uzeti prethodno spomenuti pogranični spor Grčke i Bugarske 1925. (kada je vijeće Lige naroda nametnulo primirje i povlačenje grčkih postrojbi iz Bugarske, a zatim i isplatu reparacija od strane Grčke), spor Perua i Kolumbije iz 1932. (zbog okupacije kolumbijske pokrajine Letizia od strane peruanskih postrojbi), kao i spor Paragvaja i Bolivije iz 1932. (zbog napada paragvajskih postrojbi u bolivijskoj oblasti Chaco). ${ }^{55} \mathrm{~S}$ druge strane, zanimljivo je da su sankcije protiv država koje su prekršile obveze iz Pakta Lige naroda bile primijenjene tek dvaput: 1935. prema Italiji zbog agresije na Abesiniju (današnju Etiopiju) i 1939. prema SSSR-u zbog agresije na Finsku. Za razliku od SSSR-a, koji je na temelju čl. 16. st. 4. bio isključen iz članstva, Italiji su bile izrečene tek djelomične ekonomske sankcije na temelju čl. 16. st. 1. (kroz embargo na oružje Italiji, zabranu zajmova i kredita talijanskoj vladi, zabranu izvoza i uvoza određenih dobara itd.), dok su posve izostale sankcije u formi prekida prometnih i komunikacijskih veza te diplomatskih odnosa; unatoč takvim sankcijama, Italija je anektirala Abesiniju, a već 1936., prešutno prihvativši takav status, Liga naroda je ukinula sankcije Italiji, koja je napustila članstvo u njoj $1937 .{ }^{56} \mathrm{Uz}$ to, među neuspjehe Lige naroda svakako vrijedi ubrojiti japansko zauzimanje Mandžurije. Naime, nakon što su u rujnu 1931. japanske trupe napale Mandžuriju, vijeće Lige naroda oklijevalo je s primjenom sankcija protiv Japana jer Velika Britanija i Francusk ${ }^{57}$ zbog okrenutosti prema teškim gospodarskim nedaćama tada nisu bile spremne na sukob koji bi mogao eskalirati u veliki rat s Japanom, a SAD je dao naznaku da neće podržati nikakve drastične mjere. ${ }^{58}$ Vidjevši neodlučnost Lige naroda da ozbiljno reagira, Japan je nastavio s agresijom i 28. veljače 1932. proglašena je neovisnost tog područja Kine kao posebne države Mandžukuo. Skupština Lige naroda samo je proglasila da se Japan ogriješio o međunarodne sporazume - propustivši ga označiti kao agresora i sankcionirati - te pozvala članice da ne priznaju tu državu, što je potaknulo Japan da 27.

54 Đipalo, S., Pravedni rat - osvrt na staru doktrinu u suvremeno doba i slučaj ruske intervencije u Ukrajini 2014. godine, Zagrebačka pravna revija, sv. 4, br. 1, 2015., str. 68.

55 Degan, V.-Đ., Međunarodno pravo, Školska knjiga, Zagreb, 2011., str. 54.-55.

56 Lapaš, op. cit. u bilj. 22, str. 23.; Degan, op. cit. u bilj. 55, str. 55. Do ukidanja sankcija Italiji došlo je od strane Britanaca koji su, pribojavajući se njemačke prijetnje, tako reagirali na militarizaciju Rajnske oblasti. Vidjeti: Bennett; Oliver, op. cit. u bilj. 40, str. 45.

57 Lovrenčić navodi da je jedan od razloga "mlakosti zapadnih velesila" bio u tome što u Mandžuriji nisu imale niti većih interesa niti značajnih pozicija. Vidjeti: Lovrenčić, op. cit. u bilj. 41, str. 183.

58 Johnson to pripisuje tadašnjem sve većem izolacionizmu SAD-a koji je polako smjerao prema Zakonu o neutralnosti iz 1935. Vidjeti: Johnson, op. cit. u bilj. 33, str. 324. 


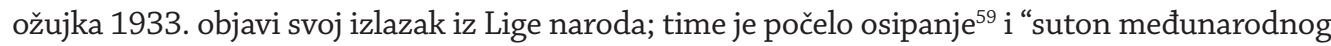
ugleda" koji je dotad Lige naroda imala. ${ }^{60}$ Njezin utjecaj kopnio je gubitkom volje članica za daljnjom suradnjom te je, naposljetku, Liga naroda ukinuta rezolucijom skupštine članica u travnju 1946. ${ }^{61}$ nakon što je već stupila na snagu Povelja Ujedinjenih naroda. Na posljednjoj skupštini Lige naroda, lord Cecil poentirao je da je Liga naroda bila "veliki eksperiment" koji je iza sebe ostavio nasljeđe u obliku "sveopćeg prihvaćanja zamisli da bi sve nacije svijeta mogle i morale surađivati radi kolektivne sigurnosti svih". ${ }^{2}$

\section{ZAKLJUČNA RAZMATRANJA}

Polazeći od tek jednog u nizu primjera koji su aktualizirali pitanje razumijevanja sustava kolektivne sigurnosti i ukazali na važnost učinkovitog funkcioniranja mehanizama iz temeljnih akata međunarodnih sigurnosnih organizacija, u ovom radu nastojalo se primjenom pravnoga, politološkog i povijesnog pristupa na sustavan način razmotriti kolektivnu sigurnost i njezine mehanizme sadržane u Paktu Lige naroda. Radi toga u radu su pobliže razmotreni njezini mehanizmi u Paktu Lige naroda kako bi se istražilo, prvo, u kojim su odredbama bili sadržani ti mehanizmi i u čemu su se oni sastojali; drugo, zašto ti mehanizmi nisu uspjeli ostvariti svoju svrhu.

U kontekstu teme ovog rada izdvojeni su čl. 10.-16. Pakta Lige naroda, pri čemu je najprije apostrofiran čl. 10. kojim je bila predviđena obveza članica da poštuju i održavaju protiv svakoga vanjskog napada teritorijalni integritet i političku neovisnost svake članice, dok je vijeće Lige naroda brinulo o sredstvima kojima se osiguravalo izvršenje te obveze. Na tu odredbu čl. 10. naslanjao se čl. 11. st. 1., prema kojemu su svaki rat ili prijetnja ratom bili od interesa za čitavu Ligu naroda koja je morala poduzeti prikladne mjere za očuvanje mira, kao i mehanizam iz čl. 12. kojim je propisan sustav prevencije oružanih sukoba obvezom članica da spor najprije pokušaju riješiti mirnim putem, uz zabranu pribjegavanja ratu prije proteka roka od tri mjeseca od arbitražne, odnosno sudske odluke ili izvješća vijeća, pri čemu je daljnja razrada tog mehanizma bila uređena u čl. 13.-15. U slučaju povrede obveza iz tih članaka, mehanizam prevencije zamijenjen je mehanizmom sankcije iz čl. 16., budući da se smatralo kako je povredom tih svojih obveza članica stupila u rat protiv svih ostalih članica koje su, pak, odmah morale aktivirati ekonomske mjere $u$ formi prekida trgovinskih, financijskih ili osobnih odnosa između njihovih državljana i državljana te članice i obustavu svih financijskih, trgovinskih ili osobnih odnosa između njihovih državljana i državljana te članice. Uz to, vijeće Lige naroda u okviru vojnih mjera moralo je preporučiti (dakle, ne i naložiti) vladama članica kojim vojnim, pomorskim ili zračnim snagama svaka od njih doprinosi oružanim snagama radi zaštite zajedničkih obveza, a u istom cilju članice su morale olakšati prolaz kroz svoj teritorij snagama

59 Popis svih članica Lige naroda, s datumima stupanja u članstvo, istupanja iz članstva i jedinog isključenja (SSSR-a) dostupan je na: National membership of the League of nations, URL= http://indiana.edu/ league/nationalmember.htm. Pristupljeno 5. ožujka 2017.

60 Lovrenčić, op. cit. u bilj. 41, str. 181.-183.

61 Resolution for the Dissolution of the League of Nations, URL= http://www.jstor.org/stable/2703564. Pristupljeno 5. ožujka 2017.

62 MacMillan, op. cit. u bilj. 37, str. 122. 
svake članice koja je sudjelovala u zajedničkoj akciji. Uza sve, članica koja se ogriješila o neke obveze iz Pakta Lige naroda mogla je (drugim riječima, nije morala) biti isključena iz članstva Lige naroda, s time da je do njezina isključenja dolazilo glasovanjem ostalih članica zastupanih u vijeću Lige naroda. Nadalje, u radu je utvrđen i dodatni sigurnosni mehanizam u čl. 21. kojim je bilo određeno da odredbe Pakta Lige naroda ne utječu na valjanost međunarodnih obveza, poput sporazuma o arbitraži i regionalnih sporazuma, kao što je Monroeva doktrina, kojima se osigurava očuvanje mira.

U nastojanju da se istraži zašto mehanizmi kolektivne sigurnosti u slučaju Lige naroda nisu uspjeli ostvariti svoju svrhu, utvrđeno je da su temeljni nedostaci Pakta Lige naroda bili u tome što nije u cijelosti zabranjivao rat ni primjenu sile, kao i u tome što vijeće Lige naroda nije imalo ovlast obvezati nego samo uputiti preporuku članicama da stave na raspolaganje vojne snage i sredstva, a usto nije bilo predviđeno ni središnje upravljanje pojedinim akcijama protiv članica koje su prekršile obveze iz Pakta Lige naroda. ${ }^{63}$ Sankcije protiv država koje su prekršile obveze iz Pakta Lige naroda primijenjene su tek dvaput: 1935. prema Italiji zbog agresije na Abesiniju i 1939. prema SSSR-u zbog agresije na Finsku. S druge strane, Liga naroda nije uspjela zaustaviti agresiju Japana na Mandžuriju (1931.), zaposjedanje Rajnske zone od strane Njemačke (1936.), kao ni zaposjedanje istočnih dijelova Poljske od strane SSSR-a (1939.); štoviše, Japan, Njemačka i Italija činili su Ligu naroda posve izlišnom time što su najprije započeli ratove, a zatim istupili iz Lige naroda.$^{64}$ Iako se u Ligi naroda tijekom prvog desetljeća njezina rada raspravljalo o najmanje 30 sporova, od kojih je većina s uspjehom riješena, postupno je - kako zbog nepristupanja SAD-a Ligi naroda, tako i zbog nepostojanja učinkovitih sredstava za postizanje njezinih ciljeva - njezin utjecaj kopnio gubitkom volje članica za daljnjom suradnjom $^{65}$ te je, naposljetku, došlo do njezina ukidanja zaključkom skupštine članica 1946.

Iako su iz današnje perspektive mehanizmi kolektivne sigurnosti u okviru Pakta Lige naroda ostali tek neuspio pokušaj sprječavanja budućih ratova na globalnoj razini koji je uskoro zamijenjen mehanizmima kolektivne sigurnosti u okviru Povelje Ujedinjenih naroda, sve češći i veći sigurnosni izazovi u svijetu iznova upozoravaju na neke od povijesnih lekcija spomenutih u ovom radu, ističući važnost razumijevanja mehanizama kolektivne sigurnosti, ali i prijetećih posljedica neučinkovitosti njihove primjene. Na tom tragu, valjalo bi, primjerice, razmatrati i postojeće mehanizme kolektivne sigurnosti prema Povelji Ujedinjenih naroda, napose u kontekstu učestalog korištenja prava veta koje pokazuje da su interesi stalnih članica Vijeća sigurnosti Ujedinjenih naroda često bili različiti, zbog čega postoji zbiljska i kontinuirana prijetnja sustavu kolektivne sigurnosti od njegove paralize. No tu temu valjalo bi obuhvatiti posebnim istraživanjem.

\section{LITERATURA}

1. Abass, A., Regional Organisations and the Development of Collective Security: Beyond Chapter VIII of the UN Charter, Hart Publishing, Oxford, Portland, Oregon, 2004.

63 Lončar, A., Koncept kolektivne sigurnosti i mirovne operacije Ujedinjenih naroda, Pravnik, god. 45, br. 90, 2011., str. 37.-38.

64 Rudolf, D., Lekcije Prvoga svjetskoga rata: uz stotu obljetnicu Prvoga svjetskog rata 1914.-1918. i dvjestotu Bečkoga kongresa 1814., Adrias, sv. 20, 2014., str. 109.

65 Bennett; Oliver, op. cit. u bilj. 40, str. 43.-49. 
2. Andrassy, J., Liga naroda: njezino ustrojstvo i djelovanje, Izdanje Pramatice Nakl. K. D: Petar Kvaternik i drugovi, Zagreb, 1931.

3. Barić, R., Transformacija NATO-a i hrvatska obrambena reforma, Polemos, god. 7, br. 13, 2004., str. 45.-89.

4. Bennett, A. L.; Oliver, J. K. Međunarodne organizacije, Politička kultura, Zagreb, 2004.

5. Bourne, M., Understanding Security, Palgrave MacMillan, Basingstoke, 2014.

6. British and Foreign State Papers 1812-1814, Vol. I, Part. I., James Ridgway and Sons, London, 1841.

7. Čehulić Vukadinović, L., NATO - od sustava kolektivne sigurnosti do unipolarnog američkog vodstva, Centar za međunarodne studije, Udruga za međunarodne studije, Zagreb, 2003.

8. Degan, V.-Đ., Odgovornost za zločin agresije u svim njegovim aspektima. Rad Hrvatske akademije znanosti i umjetnosti. Razred za društvene znanosti, br. 510=48, 2011., str. 233.-289.

9. Degan, V.-Đ., Međunarodno pravo, Školska knjiga, Zagreb, 2011.

10. Đipalo, S., Pravedni rat - osvrt na staru doktrinu u suvremeno doba i slučaj ruske intervencije u Ukrajini 2014. godine, Zagrebačka pravna revija, sv. 4, br. 1, 2015., str. 65.-90.

11. Ejdus, F., Međunarodna bezbednost: teorije, sektori i nivoi, Službeni glasnik, Beograd, 2012.

12. Gerrity, F. X. (ur.), Taft Papers on the League of Nations, Vol. 7, The Collected Works of William Howard Taft, Ohio University Press, Athens, 2003.

13. Ginneken, A. H. M., Van, Historical Dictionary of the League of Nations, Scarecrow Press, Lanham, Toronto, Oxford, 2006.

14. Ibler, V., Rječnik međunarodnog javnog prava, Informator, Zagreb, 1987.

15. Ibler, V., Kolektivna sigurnost i vanjska politika Hrvatske, Politička misao, god. 31, br. 1, 1994., str. 26.-43.

16. Johnson, P., Moderna vremena: povijest svijeta od 1920-ih do 2000, Golden marketing - Tehnička knjiga, Zagreb, 2007.

17. Kardum, L., Suton stare Europe: europska diplomacija i Prvi svjetski rat, Golden marketing - Tehnička knjiga, Zagreb, 2009.

18. Lapaš, D., Pravo međunarodnih organizacija, Narodne novine, Zagreb, 2008.

19. Lapaš, D., Međunarodna organizacija kao stranka međunarodnog spora, Zbornik Pravnog fakulteta u Zagrebu, god. 62, br. 1-2, 2012., str. 711.-734.

20. Lončar, A., Koncept kolektivne sigurnosti i mirovne operacije Ujedinjenih naroda, Pravnik, god. 45, br. 90, 2011., str. 31.-48.

21. Lovrenčić, R., Nemirni mir: svijet 1918.-1939., Mala zvona, Zagreb, 2011.

22. MacMillan, M., Mirotvorci: šest mjeseci koji su promijenili svijet, Naklada Ljevak, Zagreb, 2008.

23. McClintock, C., Revolutionary Movements in Latin America: El Salvador's FMLN \& Peru's Shining Path, US Institute of Peace Press, Washington, 1998.

24. Osmańczyk, E. J.; Mango, A. Encyclopedia of the United Nations and International Agreements: G to M, Routledge, New York, 2003.

25. Pravni leksikon, Leksikografski zavod Miroslav Krleža, Zagreb, 2007.

26. Rudolf, D., Lekcije Prvoga svjetskoga rata: uz stotu obljetnicu Prvoga svjetskog rata 1914.-1918. i dvjestotu Bečkoga kongresa 1814., Adrias, sv. 20., 2014., str. 105.-116.

27. Tsagourias, N.; White, N. D. Collective Security: Theory, Law and Practice, Cambridge University Press, Cambridge, 2013.

28. Vukadinović, R., Međunarodni politički odnosi, Politička kultura, Zagreb, 2004. 
29. Wilson, G., The United Nations and collective security, Routledge Abingdon, Oxon, 2014.

\section{POPIS PROPISA}

1. Odluka o objavljivanju mnogostranih međunarodnih ugovora kojih je Republika Hrvatska stranka na temelju notifikacije o sukcesiji, Narodne novine, Međunarodni ugovori, broj 3/1995.

2. Povelja Ujedinjenih naroda, Narodne novine, Međunarodni ugovori, broj 15/1993, 7/1994.

3. Ugovor o Europskoj uniji, Službeni list Europske unije, C 326/13 od 26. listopada 2012.

4. Zakon o potvrđivanju Sjevernoatlantskog ugovora, Narodne novine, Međunarodni ugovori, broj $3 / 2009$.

\section{MREŽNI IZVORI}

1. Briand-Kellogg Pact, URL=http://avalon.law.yale.edu/20th_century/kbpact.asp. Pristupljeno 5. ožujka 2017.

2. Charter of the Organization of American States, URL=http://avalon.law.yale.edu/20th-century/decad062.asp. Pristupljeno 5. ožujka 2017.

3. Convention on financial assistance, URL=http://digital.library.northwestern.edu/league/le000037. pdf. Pristupljeno 5. ožujka 2017.

4. Emmott, R., France makes formal call for EU military help, 2015. URL=http://in.reuters.com/article/ france-shooting-eu-defence-idINKCNOT60XJ20151117. Pristupljeno 5. ožujka 2017.

5. National membership of the League of nations, URL=http://indiana.edu/ league/nationalmember. htm. Pristupljeno 5. ožujka 2017.

6. President Woodrow Wilson's Fourteen Points, URL=http://avalon.law.yale.edu/20th-century/wilson14.asp. Pristupljeno 5. ožujka 2017.

7. Resolution for the Dissolution of the League of Nations, URL=http://www.jstor.org/stable/2703564. Pristupljeno 5. ožujka 2017.

8. Sharp, A. Collective Security, URL=www.ieg-ego.eu/sharpa-2013-en. Pristupljeno 5. ožujka 2017.

9. Tabak, I., Kolektivna obrana EU na francuski način, URL=http://obris.org/hrvatska/kolektivna-obrana-eu-na-francuski-nacin. Pristupljeno 5. ožujka 2017.

10. The Covenant of the League of Nations, URL=http://avalon.law.yale.edu/20th-century/leagcov.asp. Pristupljeno 5. ožujka 2017.

11. Treaty of Mutual Guarantee between Germany, Belgium, France, Great Britain and Italy; October 16, 1925 (The Locarno Pact), URL=http://avalon.law.yale.edu/20th-century/locarno-001.asp. Pristupljeno 5. ožujka 2017.

12. Treaty of Versailles, URL=http://loc.gov/law/help/us-treaties/bevans/m-ust000002-0043.pdf. Pristupljeno 5. ožujka 2017.

13. Treaty of Westphalia, URL=http://avalon.law.yale.edu/17th-century/westphal.asp. Pristupljeno 5. ožujka 2017.

14. Woodrow Wilson, Address delivered at the First Annual Assemblage of the League to Enforce Peace: "American Principles", URL=http://www.presidency.ucsb.edu/ws/?pid=65391. Pristupljeno 5. ožujka 2017. 


\section{COLLECTIVE SECURITY AND ITS MECHANISMS IN THE COVENANT OF THE LEAGUE OF NATIONS}

\section{Summary}

Although the idea of collective security has long existed in the history of international relations, the League of Nations was the first modern international organisation based on the idea of collective security at the global level. In this context, the author aims at giving a systematic review of collective security and its mechanisms comprised in the Covenant of the League of Nations. To this end, after introductory considerations and a short review of the conceptual definition, postulates, roots, and critiques of collective security, the paper discusses its mechanisms in the Covenant of the League of Nations in order to examine, firstly, which provisions encompassed these mechanisms and what they were composed of and secondly, why these mechanisms failed to achieve their purpose. For this reason, the conclusions in this paper rely on a normative analysis of the Covenant of the League of Nations, as well as on the specific examples from the history of international relations during the period considered.

Keywords: $\quad$ Collective security, League of Nations, Covenant of the League of Nations

\section{(i) (8)}

This work is licensed under a Creative Commons

Attribution-NonCommercial 4.0 International License.

* Gordan Struić, master of laws and university specialist in comparative politics, Croatian Parliament, Trg svetoga Marka 6, 10000 Zagreb, Republic of Croatia. Email address: gordan.struic@gmail.com. ORCID: http://orcid.org/0000-0001-6528-4436.

The views expressed here are solely those of the author. 